\begin{tabular}{|c|c|c|}
\hline $\begin{array}{l}\text { JURNALPENELITIAN KEPERAWATAN } \\
\text { MEDIK }\end{array}$ & VOL. 1 NO. 2 & $\begin{array}{c}\text { EDITION: NOVEMBER } 2018- \\
\text { APRIL } 2019\end{array}$ \\
\hline & http://ejournal.delihusada.ac.id/index.php/JPKM & \\
\hline
\end{tabular}

\title{
ANALISIS KARAKTERISTIK HUBUNGAN PENGETAHUAN DAN SIKAP DENGAN TINDAKAN MENGATASI PREMENSTRUASI SINDROM
}

\author{
Tiffani Tantina \\ Universitas Islam Sumatera Utara, Jl. STM No. 77 Medan \\ Email: joelfani02@gmail.com
}

\begin{abstract}
Premenstrual syndrome is quite high, with almost (75\%) of women of childbearing age around the world experiencing premenstrual syndrome. Country of Indonesia itself the number of events around (70-90\%), which occurs in women of childbearing age and more often found in women aged 20-40 years. This figure indicates that Premenstrual Syndrome in Indonesia is quite a lot that needs to be done countermeasures to stay and overcome it. Low knowledge of the various forms of adolescents have risky behavior / action. The purpose of this study was to analyze the relationship between the variables studied and knowledge with Premenstrual Actions Syndrome. This research method uses pure quantitative in cross sectional approach. The research subjects were female teenagers residing in the new village of Pancur Batu sub-district, which faced 90 people who were 12-16 years old. Random sampling technique by simple random sampling. Data analysis was done by Chi-Square test with multiple Linear regression test. The result of the study was no correlation between end result of age, education, first menstruation with action of overcoming premenstrual syndrome, the most dominant and significant variable is age, and knowledge also has a significant relationship with the action of overcoming premenstrual syndrome.
\end{abstract}

Keywords: Behaviour Intention, Characteristic, Premenstrual Syndrome.

\section{Pendahuluan}

Masa remaja adalah masa peralihan dari masa anak-anak menuju masa dewasa yang meliputi pertumbuhan dan perkembangan alamiah sebagai persiapan dalam memasuki masa dewasa. Pertumbuhan dan perkembangan yang cepat pada masa remaja meliputi aspek fisik, kognitif, dan sosial. Menurut definisi yang dirumuskan World Health Organization, remaja adalah masa pertumbuhan dan perkembangan saat individu berkembang dan menunjukkan tanda-tanda seksual sekundernya sampai ia mencapai kematangan seksual, individu mengalami perkembangan psikologi dan pola identifikasi dari kanak-kanak menjadi dewasa, terjadi peralihan dari ketergantungan sosial ekonomi yang penuh pada keadaan yang relatif lebih mandiri. Pada remaja putri pematangan seksualnya ditandai oleh menarche atau datangnya menstruasi yang pertama kali (Kusmiran, 2012).

Menstruasi/haid merupakan proses keluarnya darah dari kemaluan perempuan yang sehat dan tidak hamil, setiap bulan secara teratur. Pendarahan haid (menarche) menjadi tanda seseorang wanita tidak hamil dalam masa reproduksi. Menarche juga merupakan tanda awal masuknya seorang perempuan dalam masa reproduksi. Menarche dapat terjadi lebih awal pada usia 9-10 tahun atau lebih lambat pada usia 17 tahun. Secara umum rata-rata usia menarche 13-14 tahun dan terjadi pada 37,5\% anak Indonesia (Depkes RI, 2010). 


\begin{tabular}{c|c|c}
\hline $\begin{array}{c}\text { JURNALPENELITIAN KEPERAWATAN } \\
\text { MEDIK }\end{array}$ & VOL. 1 NO. 2 & $\begin{array}{c}\text { EDITION: NOVEMBER 2018 - } \\
\text { APRIL 2019 }\end{array}$ \\
\hline & http://ejournal.delihusada.ac.id/index.php/JPKM & \\
\cline { 2 - 3 } RECEIVED: 6 JANUARI 2019 & REVISED: 8 FEBRUARI 2019 & ACCEPTED: 8 MARET 2019 \\
\hline
\end{tabular}

Masalah yang timbul pada haid menjadi masalah ginekologi yang sering dikeluhkan oleh remaja. Salah satu gangguan yang berhubungan dengan haid adalah sindroma haid atau dikenal dengan premenstruasi sindrom. Masalah tersebut berupa kejadian mengalami menstruasi awal sampai menstruasi berat dan berkepanjangan, tidak teratur, rasa sakit saat menjelang haid atau saat haid datang (Neila, 2011). Gangguan menstruasi menjadi permasalahan utama pada remaja dan wanita dewasa di Indonesia (Dhamayanti, 2013).

Premenstruasi sindrom ditandai dengan gejala ketidaknyamanan perut, sakit kepala, nyeri, cepat marah dan stress (Chen et al, 2014). Angka kejadian premenstruasi sindrom cukup tinggi, yaitu hampir $75 \%$ wanita usia subur di seluruh dunia mengalami premenstruasi sindrom (Yonkers, 2008). Negara Indonesia sendiri mencatat angka kejadiannya sekitar 7090\% (Saryono \& Sejati, 2009) terjadi pada wanita usia subur dan lebih sering ditemukan pada wanita yang berusia 20-40 tahun (Wulandari, 2012).

Hasil studi lain di Iran, ditemukan sekitar $98,2 \%$ perempuan yang berumur 18-27 tahun mengalami paling sedikit satu gejala premenstruasi sindrom ringan atau sedang (Basir et al, 2012; Mahin, 2011). Survey lain menunjukkan bahwa premenstruasi sindrom merupakan masalah kesehatan umum yang paling banyak dilaporkan oleh perempuan muda dengan masa reproduksi yang belum berstatus kawin, belum kawin, ataupun janda.

Menurut Badan Kesejahteraan Keluarga Berencana Nasional (BKKBN), wanita usia subur atau wanita usia reproduktif yang berumur 18-49 tahun mengalami masalah menstruasi dengan prevalensi dari gejala klinis yang berarti adalah sekitar 12,6\%-31\%. Pengetahuan tentang ini masih relatif rendah, yakni $30 \%$ dari sekitar $50 \%$ dari remaja yang berpendidikan rendah/sekolah dasar (SD). Pengetahuan remaja terhadap resiko kehamilan semakin meningkat seiring peningkatan jenjang pendidikan yang dimiliki remaja tersebut (BKKBN, 2010) pada perilaku yang akan dilakukan atau intensi (niat) behavioral untuk melakukan tindakan kesehatan yang teratur, dimana terdapat kemungkinan yang semakin meningkat untuk melakukan tindakan kesehatan tersebut (Neila, 2011).

\section{MetOde Penelitian}

Penelitian ini menggunakan jenis penelitian kuantitatif murni dengan menggunakan rancangan Cross Sectional, bertujuan untuk melakukan pengukuran atau pengamatan yang dilakukan pada saat bersamaan pada data variabel independen dan dependen (sekali waktu).

Penelitian ini dilaksanakan di Desa Baru Kecamatan Pancur Batu Kabupaten Deli Serdang pada bulan Maret - Mei tahun 2018. Populasi dalam penelitian ini adalah seluruh remaja putri yang berusia kurang dari 12 tahun) dan lebih dari 12 tahun di Desa Baru sebanyak 3.674 orang. Sampel penelitian ini adalah sebanyak 90 orang, diambil dari satu dari 5 dusun yang ada di Desa Baru Kecamatan Pancur Batu menggunakan random sampling. Sampel adalah remaja putri yang berusia kurang dari 12 tahun dan lebih dari 12 tahun. Apabila tidak mencukupi pengambilan sampel dalam satu dusun akan diambil di dusun yang lain dalam jumlah yang dibutuhkan dan sesuai dengan karakteristik kriteria inklusi dan kriteria ekslusi yang akan diteliti.

\section{HASIL PENELITIAN}

Hasil analisis hubungan umur dengan tindakan menunjukkan bahwa remaja putri berumur kurang dari 12 tahun melakukan tindakan yang kurang baik ada 32 orang $(78,0 \%)$ lebih besar dibandingkan remaja putri berumur lebih dari 12 tahun dalam melakukan tindakan yang kurang baik yakni 27 orang $(55,1 \%)$. Dari hasil uji statistik chi square diperoleh nilai $p$ sebesar 0,023 . Artinya ada hubungan yang signifikan 


\begin{tabular}{|c|c|c|}
\hline $\begin{array}{l}\text { JURNALPENELITIAN KEPERAWATAN } \\
\text { MEDIK }\end{array}$ & VOL. 1 NO. 2 & $\begin{array}{c}\text { EDITION: NOVEMBER } 2018- \\
\text { APRIL } 2019\end{array}$ \\
\hline & http://ejournal.delihusada.ac.id/index.php/JPKM & \\
\hline
\end{tabular}

antara umur dengan tindakan mengatasi premenstruasi sindrom dengan nilai RP sebesar 1,416 (95\% CI 1,049-1,913), berarti responden yang berumur kurang dari 12 tahun memiliki peluang 1,416 kali lebih besar melakukan tindakan kurang baik dibandingkan dengan remaja putri berumur lebih dari 12 tahun di dalam mengatasi premenstruasi sindrom.

Tabel 1. Hubungan Umur dengan Tindakan Mengatasi Premenstruasi Sindrom

\begin{tabular}{|c|c|c|c|c|c|c|c|c|}
\hline \multirow{3}{*}{ Umur } & \multicolumn{4}{|c|}{ Tindakan } & \multirow{2}{*}{\multicolumn{2}{|c|}{ Jumlah }} & \multirow{3}{*}{$\boldsymbol{P}$} & \multirow{3}{*}{$\begin{array}{c}\text { RP } \\
(95 \% \mathrm{CI})\end{array}$} \\
\hline & \multicolumn{2}{|c|}{ Kurang baik } & \multicolumn{2}{|c|}{ Baik } & & & & \\
\hline & $n$ & $\%$ & $\mathbf{n}$ & $\%$ & $\mathbf{n}$ & $\%$ & & \\
\hline \multirow{2}{*}{$\begin{array}{l}<12 \text { tahun } \\
\geq 12 \text { tahun }\end{array}$} & 32 & 78,05 & 9 & 21,95 & 41 & 100 & \multirow{2}{*}{0,023} & \multirow{3}{*}{$\begin{array}{c}1,416 \\
(1,049-1,913)\end{array}$} \\
\hline & 27 & 55,1 & 22 & 44,9 & 49 & 100 & & \\
\hline Total & 59 & & 31 & & 90 & & & \\
\hline
\end{tabular}

Hasil analisis hubungan pendidikan dengan tindakan menunjukkan bahwa remaja dengan pendidikan dasar melakukan tindakan yang kurang baik ada 28 orang sebesar $(77,8 \%)$. Sedangkan pada remaja dengan pendidikan menengah melakukan tindakan kurang baik sebesar 31 orang $(57,4 \%)$. Dari hasil uji statistik chi square diperoleh nilai $p$ sebesar 0,046 . Artinya ada hubungan yang signifikan antara pendidikan dengan tindakan mengatasi premenstruasi sindrom dengan nilai RP sebesar 1,355 (95\% CI 1,015-1,808), berarti responden yang pendidikan dasar 1,355 kali perkiraan kemungkinannya dengan tindakan kurang baik dibandingkan dengan pendidikan menengah di dalam mengatasi premenstruasi sindrom

Tabel 2. Hubungan Pendidikan dengan Tindakan Mengatasi Premenstruasi Sindrom

\begin{tabular}{|c|c|c|c|c|c|c|c|c|}
\hline \multirow{3}{*}{ Pendidikan } & \multicolumn{4}{|c|}{ Tindakan } & \multirow{2}{*}{\multicolumn{2}{|c|}{ Jumlah }} & \multirow{3}{*}{$\boldsymbol{P}$} & \multirow{3}{*}{$\begin{array}{c}\text { RP } \\
(95 \% \text { IC) }\end{array}$} \\
\hline & \multicolumn{2}{|c|}{ Kurang Baik } & \multicolumn{2}{|c|}{ Baik } & & & & \\
\hline & $\mathbf{n}$ & $\%$ & $\mathbf{n}$ & $\%$ & $\mathbf{n}$ & $\%$ & & \\
\hline Pend. Dasar & 28 & 77,8 & 8 & 22,2 & 36 & 100 & \multirow{2}{*}{0,046} & \multirow{2}{*}{$\begin{array}{c}1,355 \\
(1,015-1,808) \\
\end{array}$} \\
\hline Pend. Menengah & 31 & 57,4 & 23 & 42,6 & 54 & 100 & & \\
\hline Total & 59 & & 22 & & 90 & & & \\
\hline
\end{tabular}

Hasil analisis hubungan haid pertama dengan tindakan menunjukkan bahwa pada remaja umur kurang dari 12 tahun melakukan tindakan yang kurang baik sebanyak 30 orang $(76,9 \%)$ lebih besar dibandingkan tindakan kurang baik yang dilakukan remaja umur lebih dari 12 tahun yaitu ada sebanyak 29 orang (56,9\%). Dari hasil uji statistik chi square diperoleh nilai $p$ adalah 0,047 . Artinya ada hubungan yang signifikan antara haid pertama dengan tindakan mengatasi premenstruasi sindrom dengan nilai RP sebesar 1,353 (95\% CI 1,008-1,816), yang berarti responden haid pertama remaja umur kurang dari 12 tahun berpeluang sebesar 1,353 kali jika dibandingkan dengan tindakan kurang baik yang dilakukan remaja umur lebih dari 12 tahun di dalam mengatasi premenstruasi sindrom. 


\begin{tabular}{|c|c|c|}
\hline $\begin{array}{l}\text { JURNALPENELITIAN KEPERAWATAN } \\
\text { MEDIK }\end{array}$ & VOL. 1 NO. 2 & $\begin{array}{c}\text { EDITION: NOVEMBER } 2018- \\
\text { APRIL } 2019\end{array}$ \\
\hline & http://ejournal.delihusada.ac.id/index.php/JPKM & \\
\hline
\end{tabular}

Tabel 3. Hubungan Haid Pertama dengan Tindakan Mengatasi Premenstruasi Sindrom

\begin{tabular}{|c|c|c|c|c|c|c|c|c|}
\hline \multirow{3}{*}{ Haid Pertama } & \multicolumn{4}{|c|}{ Tindakan } & \multirow{2}{*}{\multicolumn{2}{|c|}{ Jumlah }} & \multirow{3}{*}{$\boldsymbol{P}$} & \multirow{3}{*}{$\begin{array}{c}\text { RP } \\
(95 \% \mathrm{CI})\end{array}$} \\
\hline & \multicolumn{2}{|c|}{ Rendah } & \multicolumn{2}{|c|}{ Tinggi } & & & & \\
\hline & $\mathbf{n}$ & $\%$ & $\mathbf{n}$ & $\%$ & $\mathbf{n}$ & $\%$ & & \\
\hline$<12$ tahun & 30 & 76,9 & 9 & 23,1 & 59 & 100 & & 1,353 \\
\hline$\geq 12$ tahun & 29 & 56,9 & 22 & 43,1 & 31 & 100 & 0,047 & $(1,008-1,816)$ \\
\hline Total & 59 & & 31 & & 90 & & & \\
\hline
\end{tabular}

Hasil analisis hubungan pengetahuan dengan tindakan menunjukkan bahwa remaja dengan pengetahuan yang kurang baik akan melakukan tindakan yang kurang baik sebanyak 41 orang $(75,9 \%)$. Sedangkan remaja dengan pengetahuan yang baik akan melakukan tindakan yang kurang baik sebanyak 18 orang (50,0\%). Dari hasil uji statistik chi square diperoleh nilai $p$ adalah
0,011 . Artinya ada hubungan yang signifikan antara pengetahuan dengan tindakan mengatasi premenstruasi sindrom dengan nilai RP sebesar 1,519 (95\% CI 1,060-2,176), berarti remaja yang berpengetahuan kurang baik berpeluang 1,519 kali melakukan tindakan kurang baik bila dibandingkan dengan remaja berpengetahuan baik di dalam mengatasi premenstruasi sindrom.

Tabel 4. Hubungan Pengetahuan dengan Tindakan Mengatasi Premenstruasi Sindrom

\begin{tabular}{|c|c|c|c|c|c|c|c|c|}
\hline \multirow{3}{*}{ Pengetahuan } & \multicolumn{4}{|c|}{ Tindakan } & \multirow{2}{*}{\multicolumn{2}{|c|}{ Jumlah }} & \multirow{3}{*}{$\boldsymbol{P}$} & \multirow{3}{*}{$\begin{array}{c}\text { RP } \\
(95 \% \text { CI })\end{array}$} \\
\hline & \multicolumn{2}{|c|}{ Kurang Baik } & \multicolumn{2}{|c|}{ Baik } & & & & \\
\hline & $n$ & $\%$ & $\mathbf{n}$ & $\%$ & $\mathbf{n}$ & $\%$ & & \\
\hline Kurang Baik & 41 & 75,9 & 13 & 24,1 & 54 & 100 & 0011 & 1,519 \\
\hline Baik & 18 & 50,0 & 18 & 50,0 & 36 & 100 & 0,011 & $(1,060-2,176)$ \\
\hline Total & 59 & & 31 & & 90 & & & \\
\hline
\end{tabular}

Hasil analisis hubungan sikap dengan tindakan menunjukkan bahwa sikap yang kurang baik akan melakukan tindakan yang kurang baik dalam mengatasi premenstruasi sindrom sebesar 42 orang $(73,7 \%)$. Sedangkan sikap yang baik akan melakukan tindakan yang kurang baik sebanyak 17 orang (51,5\%). Dari hasil uji statistik chi square diperoleh nilai $p$ adalah 0,033. Artinya ada hubungan yang signifikan antara sikap dengan tindakan mengatasi premenstruasi sindrom dengan nilai RP sebesar 1,430 (95\% CI 0,992-2,062), berarti responden dengan sikap yang kurang baik berpeluang 1,430 kali dalam melakukan tindakan yang kurang baik dibandingkan dengan sikap baik dengan tindakan kurang baik di dalam mengatasi premenstruasi sindrom.

Tabel 5. Hubungan Sikap dengan Tindakan Mengatasi Premenstruasi Sindrom

\begin{tabular}{|c|c|c|c|c|c|c|c|c|}
\hline \multirow{3}{*}{ Sikap } & \multicolumn{4}{|c|}{ Tindakan } & \multirow{2}{*}{\multicolumn{2}{|c|}{ Jumlah }} & \multirow{3}{*}{$\boldsymbol{P}$} & \multirow{3}{*}{$\begin{array}{c}\text { RP } \\
(95 \% \text { CI })\end{array}$} \\
\hline & \multicolumn{2}{|c|}{ Kurang Baik } & \multicolumn{2}{|c|}{ Baik } & & & & \\
\hline & $\mathbf{n}$ & $\%$ & $\mathbf{n}$ & $\%$ & $\mathbf{n}$ & $\%$ & & \\
\hline Kurang Baik & 42 & 73,7 & 15 & 26,3 & 57 & 100 & \multirow{2}{*}{0,033} & \\
\hline Baik & 17 & 51,5 & 16 & 48,5 & 33 & 100 & & \\
\hline Total & 59 & & 31 & & 90 & & & \\
\hline \multicolumn{5}{|c|}{$\begin{array}{l}\text { Hasil analisis multivariat dengan regresi logistik } \\
\text { menghasilkan } p \text { value lebih dari 0,05 untuk } \\
\text { masing-masing variabel. Pada langkah terakhir } \\
\text { tampak nilai exp }(\beta) \text { yang menunjukkan bahwa }\end{array}$} & \multicolumn{4}{|c|}{$\begin{array}{l}\text { semakin besar nilai }(\beta) / O R \text {, maka makin besar } \\
\text { pengaruh variabel tersebut terhadap variabel } \\
\text { dependent. Untuk mengetahui variabel mana } \\
\text { yang paling dominan dari keempat variabel } \\
\text { yang berhubungan dengan tindakan mengatasi }\end{array}$} \\
\hline
\end{tabular}




\begin{tabular}{c|c|c}
\hline $\begin{array}{c}\text { JURNALPENELITIAN KEPERAWATAN } \\
\text { MEDIK }\end{array}$ & VOL. 1 NO. 2 & $\begin{array}{c}\text { EDITION: NOVEMBER 2018 - } \\
\text { APRIL 2019 }\end{array}$ \\
\hline & $\begin{array}{c}\text { http://ejournal.delihusada.ac.id/index.php/JPKM } \\
\text { RECEIVED: } 6 \text { JANUARI } 2019\end{array}$ & ACCEPTED: 8 MARET 2019 \\
\cline { 2 - 3 } & REVISED: 8 FEBRUARI 2019 & ACC
\end{tabular}

premenstruasi sindrom (umur, pendidikan, haid pertama, pengetahuan, dan sikap) maka dilakukan analisis multivariat dengan menggunakan regresi logistik berganda. Berikut adalah tabel kandidatnya.

Tabel 6. Variabel Kandidat Multivariat.

\begin{tabular}{lc}
\hline \multicolumn{1}{c}{ Variabel } & $\boldsymbol{p}$ \\
\hline Umur & 0,023 \\
Pendidikan & 0,046 \\
Haid Pertama & 0,047 \\
Pengetahuan & 0,011 \\
Sikap & 0,033 \\
\hline
\end{tabular}

Berdasarkan tabel di atas dapat diketahui bahwa variabel-variabel sikap, pendidikan, dan haid pertama tidak berhubungan dengan tindakan mengatasi premenstruasi sindrom karena nilai $p$ kurang dari 0,05 sedangkan variabel sikap, pendidikan dan haid pertama akan dikeluarkan dari model karena memiliki nilai $p$ lebih dari 0.05. Oleh karena itu, variabel yang masuk kedalam kandidat model selanjutnya adalah variabel umur dan pengetahuan. Variabel yang terpilih dalam model akhir regresi logistik ditunjukkan pada tabel berikut:

Tabel 7. Uji Regresi antara Distribusi Karakteristik Responden Dengan Tindakan Mengatasi Premenstruasi Sindrom

\begin{tabular}{lccccc}
\hline Varia- & \multirow{2}{*}{ bel } & B & \multirow{2}{*}{ Sig } & Exp & \multicolumn{2}{c}{$\mathbf{9 5 \%}$ CI } \\
\cline { 5 - 6 } & & & B & Low & Up \\
\hline Umur & 1,272 & 0,009 & 3,569 & 1,38 & 9,26 \\
$\begin{array}{l}\text { Penge- } \\
\text { tahuan }\end{array}$ & 1,197 & 0,017 & 3,310 & 1,24 & 8,85 \\
\hline
\end{tabular}

Dari hasil analisis multivariat ditemukan bahwa umur merupakan variabel yang bermakna dan dominan dengan tindakan mengatasi premenstruasi sindrom, sedangkan pengetahuan bermakna dan signifikan karena nilai $\mathrm{p}<0,05$. Berarti ada hubungan antara umur dengan tindakan mengatasi premenstruasi sindrom di Desa Baru Kecamatan Pancur Batu Kabupaten Deli Serdang Tahun 2018.

\section{PEMBAHASAN}

\subsection{Hubungan Umur dengan Tindakan Mengatasi Sindrom \\ Premenstruasi}

Dari hasil analisis bivariat terdapat hubungan yang signifikan antara umur dengan tindakan mengatasi Premenstruasi Sindrom sedangkan dari hasil analisis multivariat terdapat hubungan yang paling dominan dan bermakna antara umur dengan tindakan dalam mengatasi Premenstruasi Sindrom.

Salah satu faktor resiko premenstruasi sindrom adalah usia, dimana semakin meningkatnya usia maka semakin tinggi angka kejadian premenstruasi sindrom (Ratih dkk, 2012). Sedangkan premenstruasi sindrom semakin sering dan mengganggu dengan bertambahnya usia, terutama antara usia 3045 tahun, termasuk dalam kategori resiko tinggi (Elvira, 2010) karena wanita cenderung mengalami penurunan kondisi medis yang berkaitan dengan sistem reproduksi (Mufida, 2015). Usia mempengaruhi daya tangkap dan pola pikir seseorang. Semakin bertambah usia akan semakin berkembang pula daya tangkap dan pola pikirnya sehingga pengetahuan yang diperolehnya semakin membaik (Notoatmodjo, 2003).

\subsection{Hubungan Pengetahuan Dengan Tindakan Mengatasi Premenstruasi Sindrom}

Dari hasil analisis bivariat terdapat hubungan yang signifikan antara pengetahuan dengan tindakan mengatasi Premenstruasi Sindrom sedangkan dari hasil analisis multivariat terdapat hubungan yang bermakna tapi tidak signifikan antara pengetahuan dengan tindakan dalam mengatasi Premenstruasi Sindrom.

Pengetahuan atau kognitif merupakan domain yang sangat penting akan terbentuknya tindakan seseorang. Domain tingkat pengetahuan kognitif mempunyai enam tingkat meliputi mengetahui, memahami, menggunakan, menguraikan, menyimpulkan dan mengevaluasi. Ciri pokok dalam taraf 


\begin{tabular}{|c|c|c|}
\hline $\begin{array}{l}\text { JURNALPENELITIAN KEPERAWATAN } \\
\text { MEDIK }\end{array}$ & VOL. 1 NO. 2 & $\begin{array}{c}\text { EDITION: NOVEMBER } 2018- \\
\text { APRIL } 2019\end{array}$ \\
\hline & http://ejournal.delihusada.ac.id/index.php/JPKM & \\
\hline
\end{tabular}

pengetahuan adalah ingatan tentang sesuatu yang diketahuinya baik melalui pengalaman, belajar, ataupun informasi yang diterima dari orang lain (Notoatmodjo, 2003).

\section{KESIMPULAN}

1. Tidak ada hubungan antara variabel haid pertama, pendidikan, dan sikap dengan tindakan mengatasi Premenstruasi.

2. Umur merupakan variabel yang paling dominan dalam hubungan dengan tindakan mengatasi premenstuasi sindrom.

3. Pengetahuan juga merupakan variabel yang berhubungan dalam mengatasi premenstruasi sindrom.

Disarankan untuk:

1. Remaja putri yang berusia kurang dari 12 tahun, pada segi umur dalam usia yang masih muda perlu adanya pola asuh yang baik terutama dari orang tua dan guru di sekolah serta petugas kesehatan yang ada di lingkungan tempat tinggalnya. Pada umur sangat mempengaruhi daya tangkap dan pola pikir seseorang. Semakin bertambah usia akan semakin berkembang pula daya tangkap dan pola pikirnya sehingga pengetahuan yang diperolehnya semakin membaik ini mampu berfikir dan berusaha supaya dirinya dapat mengatasi atau mengurangi gejala-gejala dari premenstruasi sindrom yang muncul, Pengetahuan remaja di Indonesia tentang kesehatan reproduksi khususnya Kesehatan Reproduksi Remaja masih sangat rendah, rendahnya pengetahuan terhadap ciri reproduksi, dapat menyebabkan remaja memiliki perilaku yang beresiko.

2. Masyarakat khususnya diperlukan Enabling Factors (faktor pendukung) yaitu lingkungan fisik dan fasilitas kesehatan dan Reinforcing Factors (faktor pendorong) yaitu tokoh masyarakat, tokoh agama, dan petugas kesehatan. Dalam berperilaku kesehatan, diperlukan pengetahuan dan kesadaran tentang manfaat perilaku kesehatan tersebut. Untuk dapat berperilaku sehat, masyarakat memerlukan sarana dan prasarana mendukung atau fasilitas yang memungkinkan terwujudnya perilaku kesehatan. Perlu dilakukan arahan dan bimbingan dalam mengenal premenstruasi sindrom di daerahnya karena akan mengakibatkan buruknya kesehatan pada khususnya seorang perempuan tentang keluhan akan gejala dari premenstruasi sindrom ini. Perlu informasi yang akurat yakni dari petugas kesehatan, baik itu bidan desa, atau dokter di puskesmas di Desa Baru Kecamatan Pancur Batu Kabupaten Deli Serdang Tahun 2018.

\section{DAFTAR PUSTAKA}

Basir et al, (2012). Peran High Sensitivity CReactive Protein (hs-CRP) Sebagai Penanda Inflamasi, Indeks Massa Tubuh, \& Lingkar Pinggang Terhadap Derajat Premenstrual Syndrome Pada Wanita Usia Subur. JST Kesehatan, Vol.2 (1), p. $9-17$.

BKKBN, (2010).Remaja Genre dan Perkawinan Dini.Diunduh dari: http://www.bkkbn.go.id/publikasi / Documents / Policy \% 20 brief \% 20 remaja \% $20 \% 20$ perkawinan \% 20 dini.pdf. (tanggal akses: februari 2018)

Chen. H. Y., Huang. B.S., Lin. Y.H., Su. I. H., Yang. S. H., Chen. J. L., Huang. J. W.,Chen. Y. C., 2014.Identifying Chinese herbal medicine for premenstrualSyndrome: implications from a nationwide database.Taiwanese Journal of Obstetrics and Gynecology.http://www.biomedcentral.c om/1472-6882/14/206

Dhamayanti M. Overview adolescent health problems and services. 10 September $2 \mathrm{~m}$ (diunduh januari 2018). Tersedia dari: http://idai.or.id/publicarticles/seputarkes ehatan-ana/overview-adolescent-healthproblems-and-services.html.

Depkes RI.(2010). Riset Kesehatan Dasar2010.Diunduh dari: http://www/ litbang.depkes.go.id/ sites / download/buku laporan Llapnas riskesdas 2010 laporan riskesdas 2010.pdf. tanggalakses: februari 2018

Kusmiran,Eny (2012).Reproduksi Remaja dan Wanita.Jakarta: Salemba Medik. 


\begin{tabular}{c|c|c}
\hline $\begin{array}{c}\text { JURNALPENELITIAN KEPERAWATAN } \\
\text { MEDIK }\end{array}$ & VOL. 1 NO. 2 & $\begin{array}{c}\text { EDITION: NOVEMBER 2018 - } \\
\text { APRIL 2019 }\end{array}$ \\
\hline & $\begin{array}{c}\text { http://ejournal.delihusada.ac.id/index.php/JPKM } \\
\text { RECEIVED: 6 JANUARI 2019 }\end{array}$ & \multirow{2}{*}{ ACCEPTED: 8 MARET 2019 } \\
\cline { 2 - 3 } & REVISED: 8 FEBRUARI 2019 & \\
\hline
\end{tabular}

Neila R, (2011). Penyusunan Alat Pengukur Berbasis(Theory of Planned Behavior). Fakultas Psikologi Universitas Gadjah Mada. Buletin Psikologi .Vol. 19 (2).

Notoatmodjo, Soekidjo., 2003. Pendidikan Dan Perilaku Kesehatan, Jakarta: PT. Rineka Cipta.

Saryono dan Sejati,W.(2010).Sindrom Premenstruasi. Yogyakarta: NuhaMedika

Wulandari, R (2012). Hubungan Aktifitas Olahraga dan Obesitas dengan Kejadian Sindrom Pramenstruasi di Desa Pucang Miliran Tulung Klaten.Skripsi (tidak diterbitkan). Surakarta: Sekolah Tinggi Ilmu kesehatan Aisyah

Mufida, E. 2015. Faktor yang Meningkatkan Risiko Premenstrual Syndrome pada Mahasiswi. Jurnal Biometrika dan Kependudukan,Vol. 4 (1), p. 7-13.

Elvira, S.D. 2010. Sindrom PraMenstruasiNormalkah? Jakarta: Fakultas Kedokteran Universitas Indonesia.

Ramadani, M. 2012. Premenstrual Syndrome (PMS). Jurnal Kesehatan Masyarakat, Vol. 7 (1), p. 21-25 